\title{
KEWENANGAN PEMERINTAH PROVINSI BALI DALAM PEMBANGUNAN PELABUHAN PARIWISATA SEBAGAI PENDUKUNG PARIWISATA BALI
}

\author{
Oleh : \\ Putri Kusuma Sanjiwani ${ }^{1}$
}

\begin{abstract}
Bali Province is a province that relies on regional revenue in the tourism sector. Equitable development between North Bali South Bali require assistance through the form of government policy. One of the Bali provincial government policy is to break the waves of tourists is to build the port infrastructure development of tourism. Theory authority and policy concepts used to solve the problems concerning the form of government policy in the Bali Provincial Tourism Port infrastructure development as the carrying capacity of tourist distribution in promoting tourism in Bali. Normative research used in analyzing problems of government authority between state-owned enterprises and local goverment in accordance with regulations Indonesian republic. Explores the principle of decentralization adopted by the government system in Indonesia with a delegation of authority from the central government to local governments. Tourism ports is essential to be realized as one of the factors of sustainable tourism in Bali.
\end{abstract}

Keywords : tourism of law, government, tourism port

\section{PENDAHULUAN}

\subsection{Latar Belakang}

Provinsi Bali merupakan Provinsi yang mengandalkan Pemasukan Asli Daerah (PAD) utama di dalam sektor pariwisata. Persaingan global membuat masyarakat lokal dan Pemerintah Daerah lebih aktif untuk melakukan pembenahan pariwisata yang berbasis budaya sesuai dengan Kode Etik Pariwisata Internasional dimana pembangunan mulai mengarah pada pembenahan di dalam infrastruktur pendukung pariwisata. Gerbang utama untuk wisatawan masuk ke Pulau Bali adalah melalui dua jalur yaitu jalur laut dan

Mahasiswi Magister Ilmu Hukum Universitas Udayana, Denpasar, Bali, Alamat Jalan Batuyang, Perum Taman Asri Blok A No. 8 Batubulan, e-mail: kusuma.sanjiwani@gmail.com jalur udara. Bandara Internasional sebagai infrastruktur jalur udara dan pelabuhan sebagai infrastruktur jalur laut

Pengembangan dan pembangunan pariwisataProvinsiBaliantarapengembangan dan pembangunan pariwisata Bali Utara dengan Bali Selatan memiliki perbedaan atau ketimpangan yang cukup siginifikan. Bali Selatan mengalami perkembangan dan pembangunan yang lebih pesat dan sangat jauh dibandingkan dengan Bali Utara. Umumnya, wisatawan berkunjung ke sebuah daerah tujuan wisata memiliki motivasi yang berbeda-beda. Berbagai macam bentuk perjalanan pariwisata digunakan untuk dapat memenuhi motivasi wisatawan dalammelihat hal-hal yang baru di daerah tujuan wisata. Wisatawan yang tersebar bertitik fokus baik dalam akomodasi dan daerah tujuan wisata 
yang terpusat di Bali Selatan. Sebagai bentuk pemecah gelombang wisatawan yang terfokus di Bali Selatan, Pemerintah Daerah Provinsi Bali sedang mengejar ketimpangan tersebut dengan pembangunan sarana infrastruktur pariwisata berupa Pelabuhan Pariwisata. Seperti yang telah kita ketahui bahwa Indonesia merupakan negara maritim, Indonesia memiliki luas wilayah perairan lebih besar dibandingkan luas wilayah daratan dengan perbadingan $2 / 3$ luas wilayah merupakan perairan dengan panjang garis pantai sepanjang $81.000 \mathrm{~km}$, maka dari itu efektifitas Pelabuhan dapat melengkapi penunjang parwisata secara keseluruhan.

Masterplan Percepatan dan Perluasan Pembangunan Ekonomi Indonesia 20112025 menetapan koridor ekonomi Bali-Nusa Tenggara sebagai pintu gerbang pariwisata nasional. Pembangunan di sektor Pariwisata merupakan pilihan utama dari Pemerintah Pusat maupun Pemerintah Daerah dengan membuat kebijakan dalam pemerataan pariwisata khususnya Pemerintah Provinsi Bali dalam pendistribusian wisatawan antara Bali Utara dengan Bali Selatan. Masterplan Percepatan dan Perluasan Pembangunan Ekonomi Indonesia adalah sebuah roadmap yang disusun sebagai upaya untuk melakukan transformasi ekonomi untuk mendorong aktivitas perekonomian sekaligus mempercepat pertumbuhan ekonomi untuk meningkatkan daya saing ${ }^{2}$. Pariwisata menduduki peringkat no. 4 setelah komoditi perkebunan seperti ekspor kelapa sawit, ekspor karet dan komoditi pertambangan minyak dan batu bara yang

PKPS Bappenas. 2011. Sustaining Partnership (Media Informasi Kerjasama Pemerintah dan Swasta) Edisi Khusus Konektivitas Nasional. Infrastuktur Reform Sector Development Program (IRSDP), Jakarta. merupakan penyumbang devisa tertinggi di Indonesia sebelum tahun 2015. Persaingan di dalam pasar global telah menciptakan adanya perubahan besar bagi perkembangan perekonomian Indonesia, adanya persaingan harga telah membuat jatuhnya harga jual komoditi ekspor di Indonesia. Peristiwa ini menyebabkan pengambil alihan posisi dimana pariwisata muncul menjadi komoditi utama penyumbang devisa atau primadona devisa terbesar di Indonesia.

Pergerakan arus pemasukan devisa membuat Pemerintah Pusat menaruh perhatian khusus pada bidang pariwisata. Pelabuhan Pariwisata merupakan infrastruktur penting di dalam pendistribusi wisatawan yang efisien untuk negara maritim seperti Indonesia yang berbentuk kepulauan. Indonesia memiliki bentang alam yang sangat luas dan indah dimana perjalanan pelayaran pariwisata menjadi sangat menarik untuk dilakukan. Kedalaman laut sebuah pelayaran pariwisata idealnya memiliki kedalaman \pm 16 meter sedangkan Provinsi Bali hanya sebatas \pm 6 meter dengan dermaga untuk pelabuhan relatif pendek sehingga kapal - kapal pesiar atau kapal - kapal berukuran besar tidak dapat berlabuh di perairan Indonesia khususnya di Provinsi Bali.

Pemerataan pembangunan dalam sektor pariwisata di Bali dapat disebar dengan dibentutuknya pelabuhan-pelabuhan baru yang khusus dibangun untuk melayani transportasi pariwisata. Beberapa titik tertentu di beberapa Kabupaten di Bali memiliki potensi yang cukup baik sebagai Pelabuhan Pariwisata. Menurut situs online Republika, Kementrian Perhubungan mengucurkan dana mencapai Rp.458 Miliar untuk pembangunan infrastruktur pelabuhan 
di Bali $^{3}$. Adapun kandidat pelabuhan yang akan dibenahi adalah :

1. Pelabuhan Tanah Ampo di Kabupaten Karangasem

2. Pelabuhan Gunaksa di Kabupaten Klungkung

3. Pelabuhan Benoa di Kota Denpasar

4. Pelabuhan Gilimanuk di Kabupaten Jembrana

Pengembangan pelabuhan dan pemisahan pelabuhan yang khusus untuk pariwisata dan bersandarnya kapal-kapal pesiar atau kapal-kapal komersil lain yang membawa wisatawan dengan pelabuhan yang bertitik fokus pada bongkar muat, perikanan atau peti kemas harus mulai diperhitungkan dan direalisasikan untuk pemerataan perkembangan pariwisata di Bali.

\subsection{Permasalahan}

Berdasarkan latar belakang masalah yang telah diuraikan diatas, maka dapat ditarik sebuah permasalahan yaitu kajian mengenai bentuk kebijakan Pemerintah Daerah Provinsi Bali dalam pembangunan infrastruktur Pelabuhan Pariwisata sebagai daya dukung pendistribusian wisatawan di dalam memajukan pariwisata Bali.

\subsection{Tujuan Penelitian}

Tujuan dalam penelitian kebijakan Pemerintah Daerah Provinsi Bali dalam pembangunan infrastruktur Pelabuhan Pariwisata sebagai daya pendukung pariwisata Provinsi Bali memiliki dua tujuan umum dan tujuan khusus yaitu :

Republika News. 2015. Empat Pelabuhan di Bali Segera Dirampungkan. Republika Online, Mahaka Group.(http://www.republika.co.id/berita/koran/ nusantara-koran/15/02/06/njc8sf25-empat-pelabuhandi-bali-segera-dirampungkan)
1. Tujuan Umum

Untuk mengetahui bagaimana bentuk pengaturan hukum dan bentuk kebijakan pemerintah sesuai dengan pembagian urusan antara Pemerintah Pusat dengan Pemerintah Daerah sesuai dengan kewenangan yang dimiliki Pemerintah Daerah dalam kewenangannya mengelola aset-aset daerah sesuai dengan otonomi dan asas desentralisasi yang dianut oleh sistem pemerintahan di Indonesia.

\section{Tujuan Khusus}

Untuk mengetahui bagaimana dampak dari bentuk kebijakan Pemerintah Daerah dalam menjalankan kewenangan sesuai denga peraturan perundang-undangan dalam meningkatkan pertumbuhan dan perkembangan pariwisata khususnya pariwisata Provinsi Bali, menyeimbangkan antara pengembangan dan pembangunan pariwisata Bali Utara dengan Bali Selatan. Hal ini menjadi hal utama dimana pariwisata merupakan salah satu komoditi utama Negara Kesatuan Republik Indonesia.

\section{METODE PENELITIAN}

Penelitian mengenai bentuk kebijakan Pemerintah Daerah Provinsi Bali dalam pembangunan infrastruktur Pelabuhan Pariwisata adalah menggunakan metode penelitian normatif, yaitu meneliti bagaimana kebijakanpemerintahdidalammembuatsuatu kebijakan baik berupa produk hukum atau kebijakan pemerintah lainnya dalam upaya memecahkan permasalahan yang terjadi. Penelitian ini menggunakan pendekatan konseptual yaitu agar dapat menganalisis suatu permasalahan sesuai dengan konsep kebijakan, dan dengan studi dokumen yaitu menganalisis suatu permasalahan dengan aturan yang berlaku sesuai dengan peraturan 
perundang-undangan di dalam hierarki tata urutan perundang-undangan yang berlaku di Indonesia.

Penelitian ini menggunakan bahan hukum yaitu bahan hukum primer dan bahan hukum sekunder. Bahan hukum primer yang digunakan adalah keseluruhan peraturan sesuai hierarki tata urutan perundangundangan dimulai dari Undang-Undang Dasar Negara Kesatuan Republik Indonesia, Undang-Undang, Peraturan Pemerintah dan seterusnya yang berhubungan dengan penelitian ini. Bahan hukum sekunder adalah pandangan-pandangan para sarjana mengenai kebijakan pemerintah, data-data yang di dapat dari buku yang berhubungan dengan penelitian ini serta kajian-kajian lain yang dapat diunduh melalui internet. Bahan-bahan hukum maupun informasi penunjang yang diperoleh akan diolah dan dianalisis melalui langkah-langkah deskripsi, interpretasi, konstruksi, evaluasi, argumentasi dan sitematisasi ${ }^{4}$.

\section{HASIL DAN PEMBAHASAN}

\subsection{Tinjauan Umum Pelabuhan Pariwisata}

Pelabuhan umumnya merupakan sebuah tempat untuk bersandar atau berlabuhnya kapal-kapal, aktivitas bongkar muat barang, naik turunnya penumpang, berbagai aktivitas lainnya seperti bersifat olahraga atau wisata bahari dan merupakan tempat terbelakang yang identik dengan pemukiman serta nuansa kumuh dari masyarakat ekonomi lemah. Citra pelabuhan

Program Studi Magister Ilmu Hukum Program Pascasarjana, Universitas Udayana. 2008. Pedoman Penulisan Usulan Penelitian dan Penulisan tesis Ilmu Hukum. Program Pascasarjana Universitas Udayana, Denpasar.hlm.13-15 pada masa modern saat ini khususnya bagi daerah yang Pendapatan Asli Daerah (PAD) mengandalkan sektor pariwisata mengalami perubahan, pelabuhan saat ini menjadi jantung kegiatan awal dimulainya pariwisata dan titik awal bagi wisatawan untuk mengenal budaya suatu daerah.

Pelabuhan diatur secara jelas di dalam Undang-Undang No. 17 Tahun 2008 tentang Pelayaran. Pelabuhan ada di bawah kementrian Kementrian Koordinator bidang Kemaritiman, dimana Kementrian ini membawahi empat kementrian yaitu :

1. Kementrian Perhubungan

2. Kementrian Kelautan dan Perikanan

3. Kementrian Pariwisata

4. Kementrian Energi dan Sumber Daya Mineral

Pada hirarki peraturan perundangundangan di Indonesia, pelabuhan diatur di dalam :

1. Undang-Undang No. 17 Tahun 2008 tentang Pelayaran

2. Peraturan Pemerintah No. 61 Tahun 2009 tentang Kepelabuhan

3. Peraturan Menteri Perhubungan No: PM 51 Tahun 2015 tentang Penyelenggaraan Pelabuhan Laut

Pelabuhan Pariwisata merupakan hal yang bersifat baru di Indonesia dan tidak semua Provinsi atau daerah memiliki Pelabuhan Pariwisata. Pelabuhan Pariwisata berbeda dengan Pelabuhan Internasional yang bersifat sebatas hanya sebagai tempat untuk naik dan turunnya penumpang tetapi Pelabuhan Pariwisata dikhususkan untuk kegiatan kepariwisataan termasuk sebagai tempat awal para wisatawan yang datang untuk melakukan aktifitas berwisata. Sebuah Pelabuhan Pariwisata harus memperhatikan kaidah-kaidah tata ruang tradisional yang 
mengadopsi tata ruang wilayah suatu negara. Pengkhususan di dalam pembedaan Pelabuhan Pariwisata dari pelabuhan pada umumnya adalah untuk membuat suatu profil baru atau wajah baru dan pencitraan berbasis budaya dari suatu daerah tujuan wisata.

Pelabuhan pariwisata rata-rata dikunjungi oleh beberapa moda transportasi laut diantaranya :

1. Kapal Pesiar (cruise line)

Terdiri dari mega cruise ship, small cruise ship (yacht), luxury cruise ship, ocean cruise ship dan expedition cruise ship.

2. Kapal Layar

3. Boat

Sifat moda transportasi laut yang bersandar di Pelabuhan Pariwisata memiliki ciri khusus yaitu digunakan untuk berwisata dan moda transportasi itu bersifat menjelajah dengan berorientasi pada sebuah perjalanan yang berpindah-pindah dari satu tempat ke tempat yang lain dalam waktu yang tidak lama (tidak pulang atau tidak menetap). Biasanya perjalanan wisata akan dilakukan dalam waktu selama berbulan-bulan.

Pelabuhan pariwisata dapat digolongkan menjadi tiga jenis pelabuhan, yaitu :

a. Port of call

Pelabuhan yang digunakan untuk kapal pesiar berlabuh untuk sementara atau beberapa saat, kapal pesiar melakukan aktivitas menurunkan penumpang yang akan mengunjungi suatu objek wisata dan kemudian wisatawan akan naik ke kapal untuk melanjutkan perjalanan kembali.

\section{b. Turnaround port}

Pelabuhan yang khusus melayani pelabuhan wisata dimana kapal pesiar akan memulai pelayaran dan kembali dari pelayarannya, dan terdapat aktivitas wisatawan untuk naik dan turun kapal. Biasanya akan ada banyak yacht atau perahu berlayar yang menambatkan jangkarnya di sisi-sisi pelabuhan.

\section{c. Home Port}

Pelabuhan dimana kapal pesiar memulai dan mengakhiri perjalanannya, perbedaannya adalah pelabuhan ini dilengkapi dengan fasilitas docking untuk perbaikan kapal.

Pelabuhan Pariwisata memiliki daya dukung dalam pengembangannya. Pelabuhan Pariwisata tidak hanya sekedar berdiri dan menunggu wisatawan untuk datang tetapi Pelabuhan Pariwisata Indonesia didukung oleh rute-rute perjalanan wisata. Kementrian Pariwisata dan Ekonomi Kreatif memiliki dua rute dalam Indonesian Sailing Destination dari kategori kapal-kalap besar sampai kapal - kapal kecil yang akan mengelilingi Indonesia untuk tujuan berwisata. Menurut Agus Priyono, Direktur Industri Pariwisata, Kementrian Pariwisata dan Ekonomi Kreatif Republik Indonesia dalam Kongres Maritim Indonesia di Yogyakarta pada 2324 September 2014, Indonesia merupakan jalur palayaran pariwisata dari Darwin to Dili, Darwin to Ambon Race, Darwin to Saumlaki, Darwin to Bali Race, Darwin to Kupang Rally, Sail Indonesia, dan Singapore Straight Regatta.

\subsection{Kewenangan Pemerintah Daerah Provinsi Bali dalam Merealisasikan Pelabuhan Pariwisata di Provinsi Bali}

Suatu Provinsi akan mengikuti arah kebijakan dari pemerintah daerah setempat yang kepala pemerintahannya dipegang oleh Gubernur, begitu juga untuk daerah 
Berikut adalah rute Indonesia Sailing Destination untuk kapal-kapal kecil yang Gambar 1 (Sumber : Kementrian Pariwisata dan Ekonomi Kreatif)

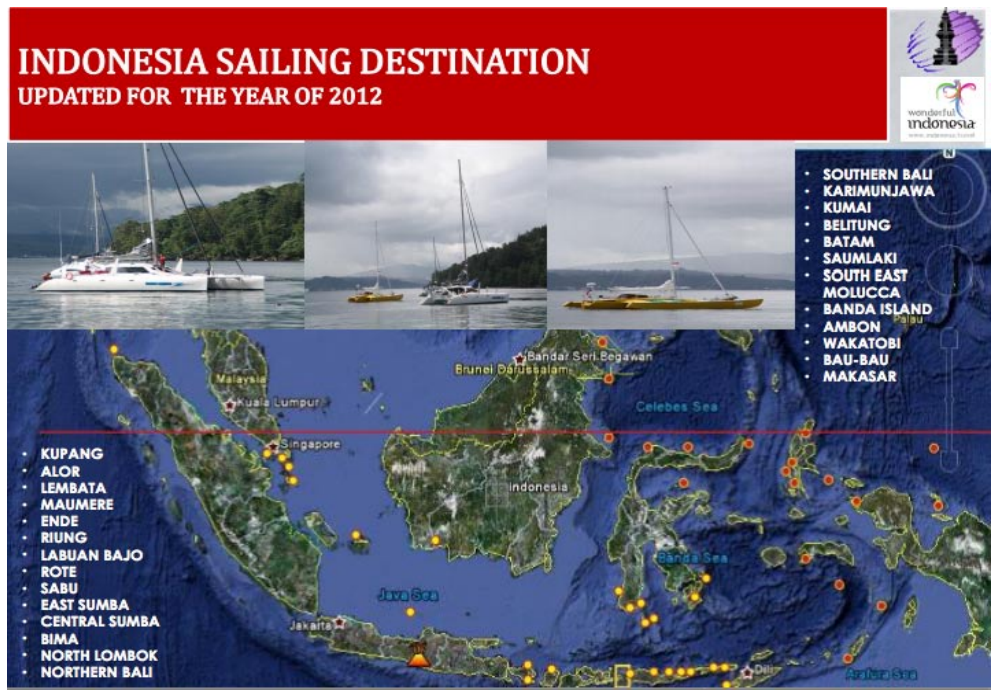

Berikut adalah rute Indonesia Sailing Destination untuk kapal pesiar dan kapal-kapal besar yang dapat dilalui di Indonesia untuk berwisata

Gambar 2

(Sumber : Kementrian Pariwisata dan Ekonomi Kreatif)

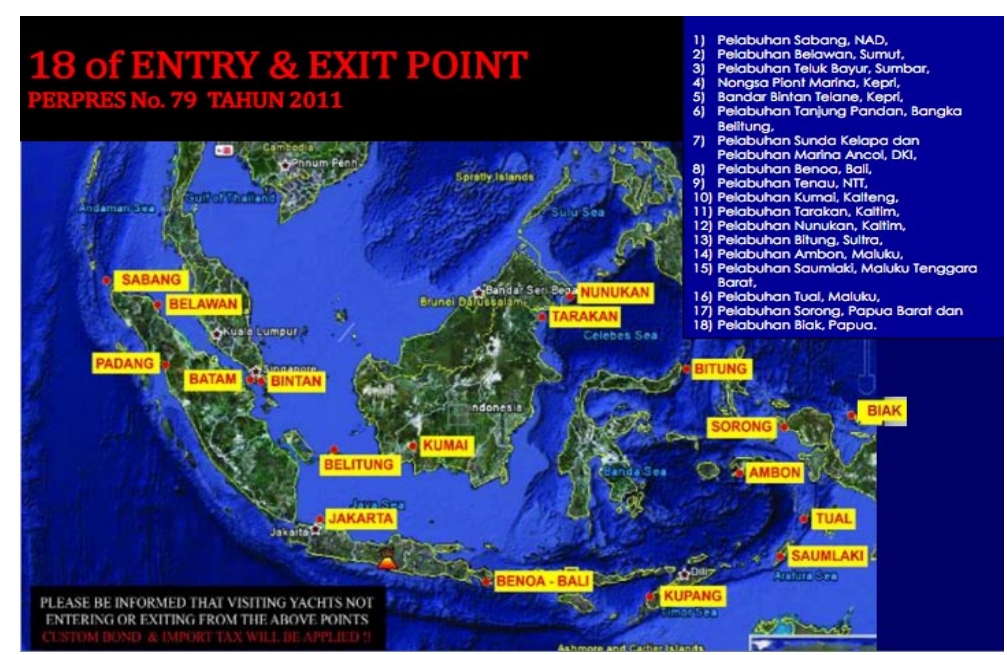

kabupaten atau kota akan akan mengikuti arah kebijakan pemerintah oleh pemerintah daerah setempat yang dikepalai oleh Bupati atau Walikota. Setiap daerah atau provinsi memiliki kebijakan yang berbeda-beda dalam pengembangan pariwisata sesuai dengan budaya dan keadaan bentang alam daerah tersebut. Menurut Dye yang dikutip oleh Winarno, kebijakan adalah sebagai pilihan pemerintah untuk melakukan atau tidak melakukan sesuatu (whatever governments choose to do or not to do $)^{5}$.

Undang-Undang No. 23 Tahun 2014 tentang Pemerintah Daerah menganut asas desentralisasi dengan pelaksanaan pembagian administrasi secara dekonsentrasi dan kewenangan secara delegasi. Pemerintah

\footnotetext{
Budi Winarno. 2002. Teori dan Proses Kebijakan Publik. Media Pressindo, Yogyakarta.
} 
Pusat sebagai pemegang kekuasaan tertinggi negara dengan dikepalai oleh Presiden membawahi kewenangan dalam pengaturan politik luar negeri, keamanan, yustisi, moneter dan fiskal nasional, dan agama. Pemerintah Daerah Provinsi dan Kabupaten diberikan kewenangan delegasi di dalam pengelolaan dan pengembangan pariwisata tetapi tetap dalam pengawasan Pemerintah Pusat dan bertanggungjawab secara penuh kepada Pemerintah Pusat. Pemerintah Daerah sebagai perpanjangan tangan Pemerintah Pusat yaitu Pemerintah Daerah Provinsi Bali melalui Dinas Pariwisata membaca tandatanda atau peluang dari pengembangan Pelabuhan sebagai Pelabuhan Pariwisata dalam memajukan Pariwisata Bali.

Pariwisata saat ini dapat dikatakan sebagai gaya hidup (life style) dan menjadi aktivitas yang wajib bagi masyarakat modern. Sesuai dengan konsep kebijakan menurut Islamy, suatu kebijakan memiliki tiga elemen yaitu ${ }^{6}$ :

1. Identifikasi dari tujuan yang ingin dicapai

2. Taktik atau strategi dari berbagai langkah untuk mencapai tujuan yang diinginkan

3. Penyediaan berbagai input untuk memungkinkan pelaksanaan secara nyata dari taktik atau strategi.

Kebijakan pembangunan Pelabuhan Pariwisata memerlukan arah kebijakan dari Pemerintah Daerah untuk merealisasikan Pelabuhan Pariwisata sebagai sebuah alternatif baru dalam promosi destinasi pariwisata.RencanapembangunanPelabuhan Pariwisata di Provinsi Bali berdasarkan :

Islamy, Irfan. 2007. Prinsip-prinsip Perumusan Kebijaksanaan Negara. Jakarta: Bumi Aksara.hlm.17.
1. Rencana Tata Ruang Wilayah Provinsi Bali

2. Rencana Tata Ruang Kabupaten

3. Tatanan Transportasi Wilayah Provinsi Bali

PT. Pelindo merupakan Badan Usaha Milik Negara yang memegang kewenangan pengelolaan Pelabuhan Benoa dan Pelabuhan Tanah Ampo sedangkan Pemerintah Daerah hanyamemilikikewenanganpadapengelolaan Pelabuhan Gilimanuk di Kabupaten Jembrana dan Pelabuhan Gunaksa di Kabupaten Klungkung. Kewenangan PT. Pelindo yang diberikan oleh Peraturan Pemerintah No. 69 Tahun 2001 tentang Kepelabuhan dianggap menjadi sebuah polemik yang menyebabkan adanya pertentangan terhadap Kewenangan PemerintahanDaerah.Pelimpahanwewenang pelabuhan dalam Undang-Undang No. 23 Tahun 2014 memberikan pelimpahan wewenang delegasi dari Pemerintah Pusat kepada Pemerintah Daerah, dimana dalam kewenangan pelabuhan masuk ke dalam kewenangan kelautan yang menjadi urusan pilihan dari Pemerintah Daerah.

PT Pelindo sebagai Badan Usaha Milik Negara berpedoman pada asas lex specilais derogat legi generalis dimana dalam hal ini Undang-Undang No. 23 Tahun 2014 tentang Pemerintah Daerah tidak mengatur secara rinci tentang Pelabuhan khususnya dalam pengelolaan dan pembangunan Pelabuhan Pariwisata sedangkan Pemerintah Daerah asas lex superiori derogat legi inferiori dimana Peraturan Pemerintah tidak boleh bertentangan dengan Undang-Undang sesuai dengan hirarki peraturan perundangundangan. Konflik norma terjadi antara Undang-Undang No.23 Tahun 2014 dengan Peraturan Pemerintah No 69 Tahun 2001. 
Pelabuhan Pariwisata merupakan suatu hal yang baru di dalam kategori pelabuhan dan suatu produk baru dalam pengembangan pariwisata.Adanyaperlakuanistimewadalam pengelolaan dan pengembangan Pelabuhan Pariwisata dalam Undang-Undang No. 23 Tahun 2014 dan Peraturan Pemerintah No. 38 Tahun 2007 merupakan sebuah kewenangan delegasi yang memberikan kewenangan kepada Pemerintah Daerah untuk dapat merealisasikan Pelabuhan Pariwisata. Kewenangan pengelolaan dan pengembangan Pelabuhan Pariwisata ini harus diatur lebih rinci lagi di dalam sebuah produk hukum berupa peraturan perundangundangan agar Pelabuhan Pariwisata dapat terealisasikan sebagai sebuah daya dukung baru pendistribusian wisatawan untuk pariwisata berkelanjutan.

\subsection{Dampak Pelabuhan Pariwisata Bagi Perkembangan Pariwisata Provinsi Bali}

Kepariwisataan menurut UndangUndang No. 10 Tahun 2009 merupakan keseluruhan kegiatan yang terkait dengan pariwisata dan bersifat multidimensi serta multidisiplin, pariwisata merupakan kebutuhan setiap orang dan negara serta interaksi antara wisatawan dan masyarakat setempat, sesama wisatawan, pemerintah, pemerintah daerah dan pengusaha. Pelabuhan pariwisata merupakan salah satu pendukung pengembangan pariwisata dalam pengembangan usaha jasa transportasi pariwisata yang bergerak dalam penyediaan angkutan khusus untuk kebutuhan dan kegiatan pariwisata. Bali merupakan salah satu tujuan dari pelayaran pariwisata internasional, negara atau daerah.
Pelabuhan Pariwisata merupakan gateway dari Provinsi Bali, Pelabuhan pariwisata dibangun untuk merangkul wisatawan asing seperti wisatawan asal Eropa dan Amerika memiliki gaya berplesiran dengan menggunakan Kapal Pesiar (cruise line). Apabila pelabuhan pariwisata dapat dikelola dengan baik dan berkelanjutan maka tidak menutup kemungkinan Pelabuhan Pariwisata juga akan menjadi tujuan wisata.

Pembangunan destinasi pariwisata merupakan program utama direktorat jenderal pengembangan destinasi pariwisata dengan enam pokok kegiatan yaitu :

a. peningkatan perencanaan destinasi dan invertasi pariwisata

b. pengembangan daya tarik wisata

c. pengembangan industri pariwisata

d. pemberdayaan masyarakat di destinasi wisata

e. pengembangan wisata minat khusus, konvensi, insentif, dan even serta dukungan manajemen dan tugas teknis pengembangan destinasi pariwisata lainnya

Pembangunan destinasi pariwisata ini akan efektif apabila Provinsi Bali mampu secara seimbang dan berkesinambungan Provinsi Bali mengusahakan adanya pemerataan distribusi wisatawan diantara pengembangan dan pembangunan Bali Utara dan Bali Selatan. Adanya Pelabuhan Pariwisata di empat titik sentral Pulau Bali dapat membantu wisatawan lebih banyak menjangkau Bali Utara dan tidak terpusat di Bali Selatan. Rencana Pelabuhan Pariwisata yaitu di Pelabuhan Tanah Ampo di Kabupaten Karangasem akan membantu distribusi wisatawan di areal Bali Timur dan Bali Utara, Pelabuhan Gunaksa di Kabupaten Klungkung akan membantu distribusi 
wisatawan di Bali Tengah, Pelabuhan Benoa di Kota Denpasar akan membantu distribusi wisatawan di Bali Selatan dan Pelabuhan Gilimanuk di Kabupaten Jembrana akan membantu distribusi wisatawan di Bali Barat dan Bali Utara.

Pelabuhan pariwisata memberi dampak baik berupa dampak positif maupun dampak negatif di dalam pariwisata yaitu :

1. Dampak Positif

a. Perkembangan Bali Utara akan menjadi lebih meningkat dalam sektor pariwisata.

b. Pemerataan pembangunan di sektor pariwisata dengan pembangunan pariwisata yang berbasis pariwisata budaya.

c. Pendistribusian wistawan yang terorganisir dengan baik akan membuat PAD daerah Kabupaten atau Kota menjadi bertambah.

d. Destinasi pariwisata di Bali Utara akan semakin berkembang.

e. Bali Utara akan menjadi pariwisata alternatif bagi Pariwisata Bali yang bertitik fokus lebih banyak di Bali Selatan.

2. Dampak Negatif

a. Kapan pesiar akan mendatangkan wisatawan dalam jumlah banyak dan hanya berplesiran dalam jangka waktu sebentar atau tidak menetap (mass tourism).

b. Adanya dualisme pengelolaan di dalam PT. Pelindo dan Pemerintah Provinsi Bali apabila belum adanya Undang-Undang atau peraturan perundang-undangan yang mengatur sistem pengelolaan Pelabuhan Pariwisata. c. Adanya limbah-limbah kapal yang dapat mencemari pantai di sekitar Pelabuhan Pariwisata.

Mass tourism yang menjadi ketakutan bagi sebuah destinasi pariwisata dapat ditanggulangi dengan adanya pemilahan wisatawan yang datang berkunjung. Undang-Undang No. 10 Tahun 2009 tentang Kepariwisataan telah mencakup pengaturan mengenai pariwisata secara general. Wisatawan yang datang walaupun dalam jumlah banyak haruslah mereka yang datang untuk tidak hanya sekedar berplesiran tetapi mereka yang akan tinggal dan berkontribusi banyak dalam daya tarik wisata tersebut. Wisatawan kapal-kapal pesiar dari Eropa dan Amerika merupakan wisatawan exclusive yang tidak akan sekedar datang lalu tidak memberikan kontribusi apa-apa di dalam pembangunan pariwisata.

\section{PENUTUP}

\subsection{Kesimpulan}

Pariwisata Bali merupakan sebuah aset yang baik bagi kemajuan Pendapatan Asli Daerah Provinsi dan menjadi salah satu penyumbang devisa terbesar sampai saat ini. Adanya dualisme kewenangan antara Pemerintah Daerah Provinsi Bali dalam merealisasikan Pelabuhan Pariwisata dan untuk pengelolaan Pelabuhan Pariwisata dengan PT. Pelindo sebagai Badan Usaha Milik Negara sebagai perwakilan Pemerintah Pusat dalam memelihara aset-aset negara membuat adanya konflik norma antara Undang-Undang No. 23 Tahun 2014 tentang Pemerintah Daerah dan Peraturan Pemerintah No. 38 Tahun 2007 tentang Pembagian Urusan Pemerintahan antara Pemerintah, Pemerintah Daerah dan Pemerintah Daerah Kabupaten atau Kota dengan Peraturan 
Pemerintah No. No. 69 Tahun 2001 tentang Kepelabuhan. Kewenangan delegasi yang dipegang oleh Pemerintah Daerah dengan Pelabuhan Pariwisata menjadi urusan pilihan dari Pemerintah Daerah menyebabkan adanya tarik menarik dengan PT. Pelindo untuk mengelola Pelabuhan Pariwisata yang akan segera direalisasikan.

Adanya dampak positif dan negatif di dalam pembanguan Pelabuhan Pariwisata harus lebih diperhatikan dimana dampak positif utama di dalam pembangunan Pelabuhan Pariwisata adalah menyasar adanya pembangunan Bali Utara yang saat ini pertumbuhan pariwisatanya masih sangat lemah serta peningkatan Pendapatan Asli Daerah di masing-masing Daerah Kabupaten atau Kota yang ada di Bali. Dampak negatif yang paling ditakuti dari sebuah Pelabuhan Pariwisata adalah adanya mass tourism di dalam pendistribusian wisatawan. Mass tourism akan membawa dampak buruk dimana wisatawan yang datang hanya sekedar berkunjung dan tidak memberika feedback bagi pemasukan daerah.

\subsection{Saran}

Pemerintah Pusat selaku pemegang kekuasaan tertinggi di dalam suatu tatanan sistem pemerintahan antara Pemerintah Pusat dan Pemerintah Daerah, harus segera merancang regulasi hukum berupa aturan yang bersifat khusus di dalam pengelolaan sebuah Pelabuhan Pariwisata yang dimana Pariwisata merupakan sebuah urusan pilihan dari sebuah Daerah baik Daerah Provinsi dan Daerah Kabupaten atau Kota. Konflik norma dapat menyebabkan ketidaklancarannya sebuah project dari Pemerintah Daerah untuk dapat mengembangkan daerahnya sendiri sesuai dengan otonomi daerah.
Adanya Analisis Dampak Lingkungan atau AMDAL yang dapat memeberikan referensi di dalam pembangunan Pelabuhan Parwisata. Kerusakan alam yang terjadi baik itu di darat, laut maupun udara juga dapat mempengaruhi pariwisata itu sendiri. Adanya empat titik Pelabuhan Pariwisata akan memberikan dampak bagi perairan di Pulau Bali. Provinsi Bali juga memiliki keindahan alam laut yang harus dijaga sebagai wisata bahari unggulan di Indonesia seperti Amed dan Pemuteran.

\section{DAFTAR PUSTAKA}

Budi Winarno. 2002. Teori dan Proses Kebijakan Publik. Media Pressindo, Yogyakarta.

Islamy, Irfan. 2007. Prinsip-prinsip Perumusan Kebijaksanaan Negara. Jakarta: Bumi Aksara.

PKPSBappenas.2011.SustainingPartnership (Media Informasi Kerjasama Pemerintah dan Swasta) Edisi Khusus Konektivitas Nasional. Infrastuktur Reform Sector Development Program (IRSDP), Jakarta.

\section{Peraturan Perundang-Undangan}

Undang-Undang Nomor 32 Tahun 2004 tentang Pemerintah Daerah (Lembaran Negara Republik Indonesia Tahun 2004 Nomor 125).

Undang-Undang No. 23 Tahun 2014 tentang Pemerintahan Daerah (Tambahan Lembaran Negara Republik Indonesia Nomor 5587).

Peraturan Pemerintah No 69 Tahun 2001 tentang Kepelabuhan (Lembaran Negara Republik Indonesia Tahun 2001 Nomor 127). 
Peraturan Pemerintah Nomor 38 Tahun

2007 tentang Pembagian Urusan

Pemerintahan antara Pemerintah,

Pemerintah Daerah Provinsi dan

Pemerintah Daerah Kabupaten / Kota.

(Lembaran Negara Republik Indonesia Nomor 4737).

\section{Artikel}

Republika News. 2015. Empat Pelabuhan di

Bali Segera Dirampungkan. Republika Online, Mahaka Group. (http:// www.republika.co.id/berita/koran/ nusantara-koran/15/02/06/njc8sf25empat-pelabuhan-di-bali-segeradirampungkan) 